\title{
PERANAN LEADERSHIP DALAM MENINGKATKAN KINERJA PEGAWAI KANTOR KELURAHAN WAUPNOR DISTRIK BIAK KOTA
}

\section{Hermanu Iriawan}

Program Studi Magister Administrasi Publik, Institut Ilmu Sosial dan Ilmu Politik YAPIS Biak

\begin{tabular}{|c|c|}
\hline Article History & \multirow{6}{*}{$\begin{array}{l}\text { Leadership merupakan usaha seseorang untuk mempengaruhi orang } \\
\text { lain. Penelitian ini bertujuan untuk mengetahui peran Leadership dalam } \\
\text { meningkatkan kinerja pegawai pada Kantor Kelurahan Waupnor Distrik } \\
\text { Biak Kota. Penelitian ini menggunakan pendekatan deskriptif analisa, } \\
\text { tehnik pengumpulan data dengan menggunakan wawancara, observasi } \\
\text { dan dokumentasi hasil penelitian menunjukkan bahwa Kemampuan } \\
\text { pimpinan dalam meningkatkan kinerja pegawai sudah menunjukkan } \\
\text { hasil yang baik meskipun pegawai masih membutuhkan perhatian, } \\
\text { motivasi serta pengawasan dari seorang pimpinan. }\end{array}$} \\
\hline Received : Jan 17, 2020 & \\
\hline Accepted : March 4, 2020 & \\
\hline Published: March 4, 2020 & \\
\hline Kata Kunci & \\
\hline $\begin{array}{l}\text { Leadership, kinerja pegawai } \\
\text { Biak }\end{array}$ & \\
\hline
\end{tabular}

\section{PENDAHULUAN}

Kepemimpinan memiliki peran penting terhadap jalannya sebuah organisasi, kepemimpinan memjadi penting oleh karena menentukan keberhasilan tujuan organisasi. Leadership mencakup pengelolaan tugas, pembagian kerja, organisasi, keputusan dan sumber-sumber dalam upaya mencapai tujuan bersama, agar menciptakan iklim kerja agar bawahan bekerja secara optimal meningkatkan produktivitas kerja demi tercapainya tujuan organisasi. Leadership terhadap bawahan merupakan kemampuan pimpinan yang mampu mengarahkan organisasi kearah pencapaian tujuan yang menguntungkan bagi pemimpin dan bawahan serta lingkungan sosial dimana mereka berada. Leadership merupakan proses terencana yang dinamis melalui suatu periode waktu dalam situasi yang didalamnya pemimpin menggunakan perilaku atau gaya kepemimpinan yang khusus dan sarana prasarana dan sumbersumber untuk menggerakan bawahan guna melaksanakan pekerjaan kearah pencapaian tujuan yang saling menguntungkan bagi pemimpin dan bawahan.

Leadership sangat penting sebagai penggerakan dan pemberian pengaruh pada kegiatan-kegiatan dari sekelompok anggota yang saling berhubungan dengan tugasnya artinya kepemimpinan sebagai motor penggerak bagi sumber-sumber dan alat-alat dalam suatu unit kerja organisasi. Sukses tidaknya suatu organisasi mencapai tujuan yang telah ditentukan tergantung atas cara-cara memimpin yang dipraktekkan oleh orang-orang atasan itu. Setiap organisasi pemerintah dituntut untuk dapat mengoptimalkan sumber daya manusia dan bagaimana sumber daya manusia dikelola.

\section{METODE DAN FOKUS PENELITIAN}

\section{Jenis Penelitian}

\footnotetext{
How to Cite (APA $6^{\text {th }}$ Edition style):

Iriawan, H. (2020). Peranan Leadership dalam Meningkatkan Kinerja Pegawai Kantor Kelurahan Waupnor Distrik Biak Kota. MUKADIMAH, 4(1), 40-45. 
Di dalam pelaksanaan penelitian penulis menggunakan metode penelitian kualitatif. Metode penelitian kualitatif adalah penelitian yang bermaksud untuk memahami fenomena tentang apa yang dialami oleh subjek penelitian misalnya perilaku, persepsi, motivasi, tindakan, dll secara holistik, dan dengan cara deskripsi dalam bentuk kata-kata dan bahasa, pada suatu konteks khusus yang alamiah dan dengan memanfaatkan berbagai metode alamiah.

\section{Tempat dan Waktu Penelitian}

Penelitian ini dilakukan di Kantor Kelurahan Waupnor Distrik Biak Kota. Penelitian selama dua bulan yaitu di mulai dari Bulan Oktober dan November 2018.

\section{Teknik Pengumpulan Data}

Teknik pengumpulan data yang digunakan dalam penelitian ini adalah wawancara, observasi dan dokumentasi.

\section{Teknik Analisis Data}

Analisis data yang digunakan adalah analisis data kualitatif. Hal ini dilakukan agar yang diperoleh dapat dilakukan pengecekan kembali dilingkungan seandainya data itu belum lengkap atau masih diragukan kebenarannya.

\section{KERANGKA TEORETIK DAN KONSEPTUAL}

Pengelolaan sumber daya manusia dimulai dari proses rekruitmen, training. Pengelolaan sumber daya manusia yang harus matang harus dimulai dari awal karena nantinya akan sangat menentukkan kelangsungan organisasi. Hal ini menjadi tanggung jawab manajemen atau pemimpin organisasi, karena itu manajemen harus mampu membuat perencanaan yang matang, menyusun strategi yang efektif serta mampu mengkoordinasikan semua komponen perusahaan pada umumnya dan sumber daya pada khususnya (Sutrisno dalam Sidanti, 2015).

Sumber daya manusia merupakan tokoh sentral dalam sebuah organisasi. Agar aktivitas manajemen berjalan dengan baik, organisasi harus memiliki pegawai yang berpengetahuan dan berketrampilan tinggi serta usaha untuk mengelola organisasi seoptimal mungkin sehingga kinerja pegawai meningkat. Organisasi yang baik adalah organisasi yang berusaha meningkatkan kemampuan sumber daya manusianya, karena hal tersebut merupakan faktor kunci untuk meningkatkan kinerja pegawai (Maria, 2013). Lebih lanjut, kepemimpinan dibutuhkan manusia karena adanya suatu keterbatasan dan kelebihan-kelebihan tertentu pada manusia. Di satu pihak, manusia terbatas kemampuannya untuk memimpin, di pihak lain ada orang yang mempunyai kelebihan kemampuan untuk memimpin. Di sinilah timbulnya kebutuhan akan pemimpin dan kepemimpinan (Edyanto, 2018).

Menurut Mutiara dalam (Edyanto, 2018) Betapa pentingnya pemimpin dan kepemimpinan dalam suatu kelompok jika terjadi suatu konflik atau perselisihan diantara orang-orang dalam kelompok, maka orang-orang mencari cara pemecahan supaya terjamin keteraturan dan dapat ditaati bersama. Kepemimpinan yang tepat juga mendukung proses pembangunan pada suatu pemerintahan, dimana ketepatan dalam 
proses pembaginan tugas dan wewenang secara tepat secara langsung akan membantu proses pencapaian tujuan pembangunan daerah yang telah ditetapkan. Lebih lanjut, manajemen kinerja adalah manajemen tentang menciptakan hubungan dan memastikan komunikasi yang efektif (Ivonne A.S. Sajangbati, 2013). Pemimpin sangat dibutuhkan untuk memberi motivasi demi pencapaian kinerja, motivasi dan kinerja adalah dua elemen yang konstruktif dan korelatif. Keduanya saling mensyaratkan dan tidak bisa dilepaskan dengan yang lain (Harlie, 2012). Kinerja para pewagai yang maksimal menjadi syarat utama bagi instansi untuk dapat memberikan pelayanan yang memuaskan.Jika instansi saja tidak dapat memberikan pelayanan yang memuaskan bagi para pegawainya, bagaima- na mungkin para pegawai serta instansi tersebut dapat memberikan pelayanan yang maksimal seperti yang diharapkan (Kurnia Riyantini dan Agus Triyono, 2016). Kinerja pelayanan publik merupakan salah satu dimensi strategis dalam menilai keberhasilan pelaksanaan otonomi daerah dewasa ini. Pemerintah (Restu Agusti, 2012).

\section{HASIL DAN PEMBAHASAN}

\section{Peran Kepemimpinan dalam Meningkatkan Kinerja}

Peran seorang pemimpinan sangat penting dalam meningkatkan kinerja pegawai suatu organisasi atau perusahaan. Segala sesuatu yang berkaitan dengan kemajuan dan kesuksesan suatu organisasi hanya dapat terlaksana oleh adanya campur tangan ataupun buah pikiran seorang pimpinan. Peran seorang pemimpin dapat diketahui melalui keberhasilannya dalam mencapai tujuan organisasi. Hasil wawancara langsung yang dilakukan kepada beberapa pegawai di Kantor Kelurahan Waupnor Distrik Biak Kota.

Hasil wawancara yang dilakukan dengan informan yang berinisial DK, mengemukakan bahwa:

"......Bahwa Pimpinan selalu memberikan motivasi/ dorongan yang cukup signifikan agar pegawai penuh semangat kerja, rajin dan penuh dedikasi yang tinggi dalam melaksanakan tugas dan melayani masyarakat secara maksimal. Kelemahannya tidak disertai pujian, imbalan jasa, dan penghargaan dalam suatu kegiatan yang dilaksanakan”.

Menurut Hasil wawancara dengan informan inisial RI mengemukakan bahwa: ".........Pimpinan selalu terbuka bagi bawahan seperti koordinasi, kerja sama, dan masalah keuangan maupun dalam menentukan kebijakan dan pengambilan keputusan. Pimpinan selalu mengadakan pengawasan terhadap kinerja pegawai menyangkut kedisiplinan, tanggung jawab dan waktu kerja, misalnya ada pegawai yang Indisipliner ditegur secara lisan dan dinasehati. Disamping itu pimpinan selalu memberi dorongan, pengarahan pegawai dalam pertemuan-pertemuan agar bekerja dengan rajin secara ikhlas dan suka rela tanpa pamrih dan kerja sama satu dengan yang lain serta saling membantu menyelesaikan pekerjaan teman apabila 
yang bersangkutan berhalangan dengan maksud agar pelayan terhadap masyarakat berjalan lancar".

\section{Faktor Penghambat terhadap Kinerja}

Adapun faktor penghambat Kinerja pegawai Kantor Kelurahan Waupnor Distrik Biak Kota adalah :

1. Disiplin Kerja Pegawai dalam melaksanakan tugas kurang mendapat perhatian dan sering diabaikan. Tentu berdampak pada kualitas kinerja yang mana pegawai kurang bekerja secara maksimal dan menghasilkan produktifitas yang tinggi.

2. Motivasi kelemahannya tidak disertai pujian, imbalan jasa, dan penghargaan kepada pegawai dalam kegiatan tertentu sehingga kurang mendorong semangat kerja.

3. Tanggung jawab sering tidak dilaksanakan sebagaimana mestinya dianggap sebagai suatu beban kerja yang memberatkan sehingga tidak melaksanakan tugas dengan baik.

4. Waktu Kerja salah satu faktor yang kurang mendapat perhatian pegawai terutama mematuhi jam kerja kantor. Faktor waktu kerja sangat penting karena merupakan kesempatan bagi pegawai untuk menyelesaikan tugas pekerjaannya.

5. Pengawasan Pimpinan terhadap kinerja pegawai berjalan secara kontinyu namun kelemahannya ada pegawai yang tidak menerima teguran pimpinan.

6. Transparansi secara terbuka kepada bawahan baik koordinasi, kerja sama dan pengambilan keputusan. Kelemahannya ada pegawai yang tidak mematuhi kebijakan dan pengambilan keputusan bersama.

7. Mutu Kerja pada umumnya kurang menghasilkan produktifitas kerja pegawai secara maksimal disebabkan latar belakang pendidikan.

8. Semangat kerja kurang diimbangi dengan pemberian insentif yang memadai sering berdampak pada sikap ketaatan.

\section{PENUTUP}

Peran kepemimpinan dalam menumbuhkan pemahaman dan kesadaran para pegawainya sudah bagus hanya saja masih kurang tegas kepada pegawainya, karena ketegasan seorang pemimpin menjadi salah satu faktor utama dalam hal kepemimpinan Disamping itu kemampuan pimpinan dalam meningkatkan kinerja pegawai sudah menunjukkan hasil yang baik, meskipun masih terlihat adanya pekerjaan yang dilaksanakan pegawai atau bawahan ada yang tidak sesuai dengan apa yang diperintahkan oleh atasan.

\section{REFERENSI}

Edyanto, K. (2018). Leadership Bupati Dalam Pembangunan di Kabupaten Tambrauw (Studi Kepemimpinan Bupati Tambrauw). Sosio E-Kons, 10 (2), 143-149.

Harlie, M. (2012). Pengaruh Disiplin Kerja, Motivasi dan Pengembangan Karier terhadap Kinerja Pegawai Negeri Sipil pada Pemerintah Kabupaten Tabalong di Tanjung 
Kalimantan Selatan. Jurnal Aplikasi Manajemen, 10 (4), 86o-867.

Ivonne A.S. Sajangbati. (2013). Motivasi, Disiplin, dan Kepuasan Pengaruhnya Terhadap Kinerja Pegawai PT. POS Indonesia (PERSERO) Cabang Bitung. Jurnal EMBA, 1 (4), $667-678$.

Kurnia Riyantini dan Agus Triyono. (2016). Pengaruh Kepuasan Komunikasi Organisasi Terhadap Kinerja Pegawai Di Sekretariat DPRD Kota Singkawang. Informasi, 46 (2).

Maria, A. (2013). Pengaruh Gaya Kepemimpinan, Pengaruh Sumber Daya Manusia dan Disiplin Kerja terhadap Kinerja Pegawai Sekretariat Dewan Perwakilan Rakyat Daerah Provinsi Sulawesi Tengah. Katalogis, 1(1), 95-104.

Restu Agusti. (2012). Pengaruh Partisipasi Penyusunan Anggaran Terhadap Kinerja Aparatur Pemerintah Daerah dengan Dimoderasi oleh Variabel Desentralisasi dan Budaya Organisasi (Studi Kasus Pada Pemerintah Kabupaten Bengkalis). Ekonomi, $20(3), 1-15$.

Sidanti, H. (2015). Pengaruh Lingkungan Kerja, Disiplin Kerja dan Motivasi Kerja terhadap Kinerja Pegawai Negeri Sipil di Sekretariat DPRD Kabupaten Madiun. Jurnal JIBEKA, 9 (1), 44-53. 